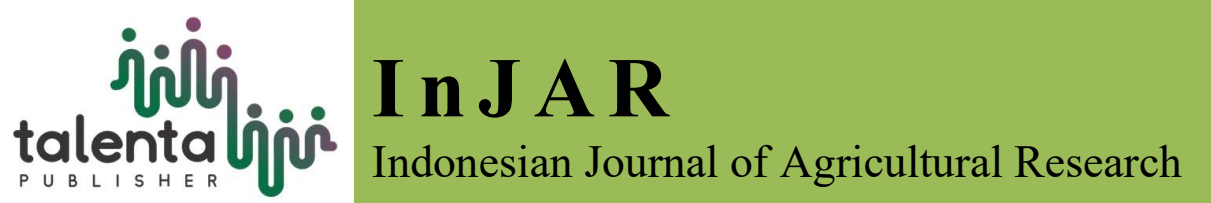

\title{
Trade Opportunity of Potential Agricultural Commodities between Turkey and Indonesia (Case Study Palm Oil)
}

\author{
Hari Haryadi ${ }^{1}$ and Cennet Oguz ${ }^{2}$ \\ ${ }^{1}$ Department Food Technology, Universitas Ahmad Dahlan, Indonesia \\ ${ }^{2}$ Department Agricultural Economics, Selcuk University, Turkey
}

\begin{abstract}
This research was conducted in Indonesia and Turkey. The aims of this study is to analyse the Strengths, Weaknesses, Opportunities, and Threats (SWOT) of trade relations in, the industry attractiveness, trade potential, strategic orientation of the palm oil commodities traded between Turkey and Indonesia, and to analyse the industry competitive forces. This research use primary and secondary data, both of quantitative and qualitative ones. The primary data obtained from deep interview by purposive sampling, Focus Group Discussion (FGD) method by online and offline communication, and from experts acquisition. The secondary data obtained from UN Comrade, FAOSTAT, IMF, World Bank, Ministry of Commerce, Ministry of Agriculture and other relevant agencies. Descriptive data were analysed using the SWOT Matrix method, the SOR (Strategic Orientation) Matrix method, Strategic Position and Action Evaluation (SPACE), and the Porter's Five Competitive Forces Matrix. Based on the diagram by the internal-external factor matrix, it is known that the condition of between Turkey and Indonesia were same condition on the Divest.
\end{abstract}

Keywords: agricultural commodities, competitive strategy, international trading

Received 20 March 2019 | Revised 02 May 2019 | Accepted 04 July 2019

\section{Introduction}

Diplomatic relation between Indonesia and Turkey has been officially opened since 1950. Since 1985 Indonesia and Turkey have conducted seven times the Joint Commission Meeting (JCM) to strengthen and develop economic and trade cooperation on the basis of mutual benefit.

At the 7th JCM in 2008 the two countries agreed to establish the Comprehensive Trade and Economic Partnership (CTEP), and signed several bilateral agreements such as Economic and Technical Cooperation Agreement, Double Taxation Avoidance Agreement, the Promotion and Protection Agreement Joint Investment and Information Exchange MoU between Bank Indonesia and the Banking Regulation and Supervision Agency of Turkey. According to

\footnotetext{
*Corresponding author at: Department Food Technology, Universitas Ahmad Dahlan, Campus IV, Jl. Ringroad Selatan, Kragilan, Tamanan, Banguntapan, Bantul, Daerah Istimewa Yogyakarta, 55191, Indonesia

E-mail address: hari.haryadi@tp.uad.ac.id
} 
Ministry of the Republic of Indonesia secretariat of state government office (2012), in 2011

Indonesia and Turkey agreed to accelerate the trade between the two countries up to U.S. $\$ 5$ billion within the next five years. [1].

Between The Government of The Republic of Indonesia and The Government of The Republic of Turkey on Agricultural Sector for a period of 5 (five) years (2008-2013) [2]. This Memorandum of Understanding (MoU) Parties shall carry out the cooperation between them in the following areas:

1. Plant production and plant protection;

2. Animal husbandry and animal health;

3. Food industry;

4. Research, rural development, irrigation and extension services;

5. Promotion of joint ventures in the field of agriculture between the private sectors of each country;

6. Other related areas that are of interest and mutually agreed upon by the Contracting Parties.

The Memorandum of Understanding (MoU) Parties agree to cooperate in the following forms [3]:

1. Exchange of information, visit, experts, research results, study and training;

2. Organization of seminars, symposia, exhibitions and conferences;

3. Any other technical form of cooperation as mutually agreed upon by the Contracting Parties [3].

\section{Research Methods}

The data used are primary and secondary data both quantitatively and qualitatively. The primary data was taken from the interviews to the national agribusiness experts and practitioners. Quantitative secondary data consists of the data time series and cross section of the year 20082011 for trade data in two countries, Turkey and Indonesia. The secondary data obtained from UN Comrade, FAOSTAT, IMF, World Bank, Ministry of Commerce, Ministry of Agriculture and other relevant agencies. The data used include data on total production, the volume of imports and exports, and international trade policy [4]. The primary data obtained from deep interview by purposive sampling, Focus Group Discussion (FGD) method by online and offline communication either, also experts acquisition.

In processing data were used both descriptive and quantitative methods. The studies determine which commodities have the potential trade who has the highest export quotation from Indonesia to Turkey. Descriptive method was used to describe the capacity of supply and demand by knowing the volume of exports and imports of major agricultural commodities in the 
country of Turkey and Indonesia, examines the trade policy and global marketing strategy in the SWOT (Strength, Weakness, Opportunity, Threat) [5] [6] matrix method,, Internal Factor Analysis (IFAS), External Factor Analysis (EFAS), Strategic Position and Action Evaluation (SPACE), and the Porter's Five Competitive Forces Matrix. Quantitative method was used to forecast the trend line of changes in demand and supply on the main commodity traded. The processing of data was performed via Microsoft Excel 2010 software and then proceeds to the stage of data interpretation.

\section{Results and Discussion}

\subsection{Analysis Trading Opportunity from Indonesia to Turkey}

Table 1. SWOT Matrix Palm Oil Trading from Indonesia to Turkey

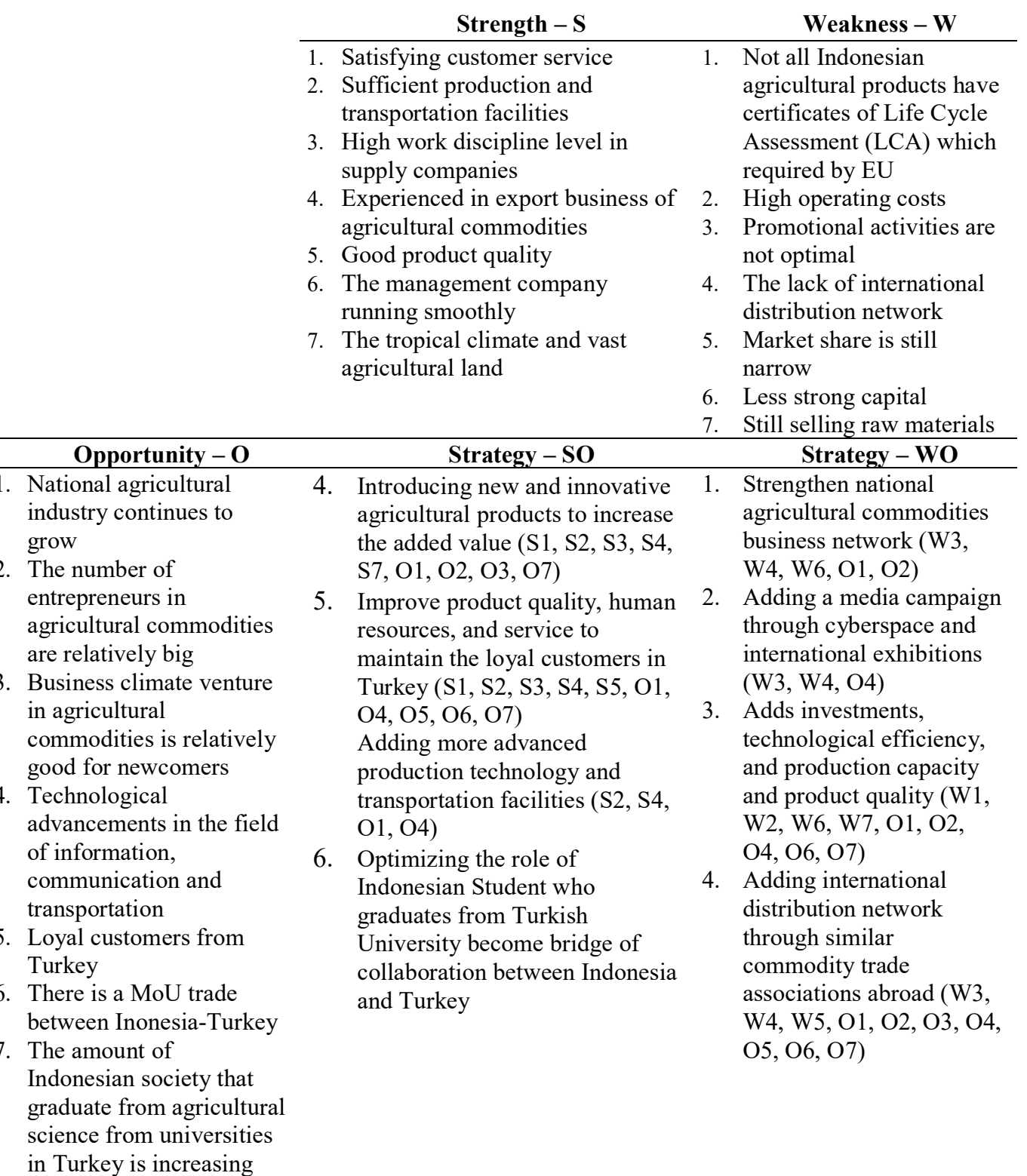

$$
\text { Threat }-\mathbf{T}
$$
Strategy - ST Strategy - WT

1. Business competition is 1. Providing compensation of social 1. Optimize production getting tougher responsibility to surrounding capacity and make cost 
2. Changes in consumer tastes

3. Indonesia's economic growth is running slowly

4. 4.Complicated and burdensome export licensing bureaucracy

5. High rates of inflation and the weakening of the rupiah

6. The issue of environmental damage due to poor farming practices

7. Complicated international trade licensing quarantine communities (S6, T1, T3, T6)

2. Lobbying the government through the agricultural commodity trade associations to apply tape in export facilities and active in international forums (S5, T4, T7)

3. Improving competitiveness through efficiency and quality (S1, S2, S3, S4, S6, S7, T1, T2, T5)

4. Improve the credibility of enterprises through the fulfillment of consumer demand and suitable to international rules $(\mathrm{S} 1, \mathrm{~S} 2, \mathrm{~S} 6$, S7, T1, T7) savings (W1, W2, W7, $\mathrm{T} 1, \mathrm{~T} 2, \mathrm{~T} 5)$

2. 2.Doing manpower recruitment marketing to Turkey (W3, W4, W5, $\mathrm{T} 1, \mathrm{~T} 2)$ Doing strategies concentration on one product line (W1, W2, W5, W6, W7, T1, T2)

Notice: Statement with red colour informed about important strategy which can be conducted

Table 2. Internal Factor Analysis (IFAS) from Indonesia to Turkey

\begin{tabular}{|c|c|c|c|c|}
\hline No & Internal Strategic Factors & Score (B) & Rating (R) & B $\times R$ \\
\hline \multirow[t]{9}{*}{1} & Strength & & & \\
\hline & Satisfactory customer service & 0.11 & 4 & 0.44 \\
\hline & adequate production and transportation facilities & 0.08 & 3 & 0.24 \\
\hline & high work discipline level in supply companies & 0.05 & 3 & 0.15 \\
\hline & $\begin{array}{l}\text { Experienced in export business of agricultural } \\
\text { commodities }\end{array}$ & 0.08 & 3 & 0.24 \\
\hline & Good quality product & 0.05 & 4 & 0.20 \\
\hline & Management of the company running smoothly & 0.06 & 3 & 0.18 \\
\hline & The tropical climate and vast agricultural land & 0.09 & 4 & 0.36 \\
\hline & Ammount & 0.52 & & 1.81 \\
\hline \multirow[t]{10}{*}{2} & Weakness & & & \\
\hline & $\begin{array}{l}\text { Not all Indonesian agricultural products have } \\
\text { certificates of Life Cycle Assessment (LCA) which } \\
\text { required by EU }\end{array}$ & 0.06 & -3 & -0.18 \\
\hline & High operating costs & 0.07 & -2 & -0.14 \\
\hline & Promotional activities are not optimal & 0.05 & -2 & -0.10 \\
\hline & the lack of international distribution network & 0.08 & -2 & -0.16 \\
\hline & Market share is still narrow & 0.06 & -3 & -0.18 \\
\hline & Less strong capital & 0.07 & -3 & -0.21 \\
\hline & Still selling raw materials & 0.09 & -3 & -0.27 \\
\hline & Ammount & 0.48 & & -1.24 \\
\hline & Total & 1.00 & & 0.57 \\
\hline
\end{tabular}

Table 3. External Factor Analysis (EFAS) from Indonesia to Turkey

\begin{tabular}{clccc}
\hline No & \multicolumn{1}{c}{ External Strategic Factors } & Score (B) & $\begin{array}{c}\text { Rating } \\
\text { (R) }\end{array}$ & B x R \\
\hline $\mathbf{1}$ & Opportunity & 0.12 & 4 & 0.48 \\
\cline { 2 - 5 } & $\begin{array}{l}\text { National agricultural industry continues to grow } \\
\text { The number of entrepreneurs in agricultural } \\
\text { commodities are relatively big }\end{array}$ & 0.09 & 3 & 0.27 \\
$\quad \begin{array}{l}\text { Business climate venture in agricultural commodities is } \\
\text { relatively good for newcomers }\end{array}$ & 0.06 & 3 & 0.18 \\
$\quad \begin{array}{l}\text { Technological advancements in the field of } \\
\text { information, communication and transportation }\end{array}$ & 0.09 & 3 & 0.27 \\
$\quad \begin{array}{l}\text { Loyal customers from abroad } \\
\text { There is a MoU trade between Inonesia-Turkey } \\
\text { the amount of Indonesian society that graduate from }\end{array}$ & 0.07 & 4 & 0.28 \\
$\quad \begin{array}{l}\text { agricultural science from universities in Turkey is } \\
\text { increasing }\end{array}$ & 0.10 & 4 & 0.44 \\
\hline
\end{tabular}




\begin{tabular}{|c|c|c|c|c|}
\hline & Amount & \multicolumn{2}{|c|}{0.64} & \multirow[t]{2}{*}{2.32} \\
\hline \multirow[t]{10}{*}{2} & Threat & & & \\
\hline & Business competition is getting tougher & 0.06 & -3 & -0.18 \\
\hline & Changes in consumer tastes & 0.07 & -2 & -0.14 \\
\hline & Indonesia's economic growth is running slowly & 0.05 & -3 & -0.10 \\
\hline & $\begin{array}{l}\text { complicated and burdensome export licensing } \\
\text { bureaucracy }\end{array}$ & 0.05 & -2 & -0.16 \\
\hline & High rates of inflation and the weakening of the rupiah & 0.05 & -4 & -0.18 \\
\hline & $\begin{array}{l}\text { The issue of environmental damage due to poor } \\
\text { farming practices }\end{array}$ & 0.03 & -3 & -0.21 \\
\hline & complicated international trade licensing quarantine & 0.05 & -3 & -0.27 \\
\hline & Amount & 0.36 & & -1.01 \\
\hline & Total & $\mathbf{1 . 0 0}$ & & 1.31 \\
\hline
\end{tabular}

Table 4. Matrix Internal-External from Indonesia to Turkey

\section{INTERNAL BUSINESS POWER}

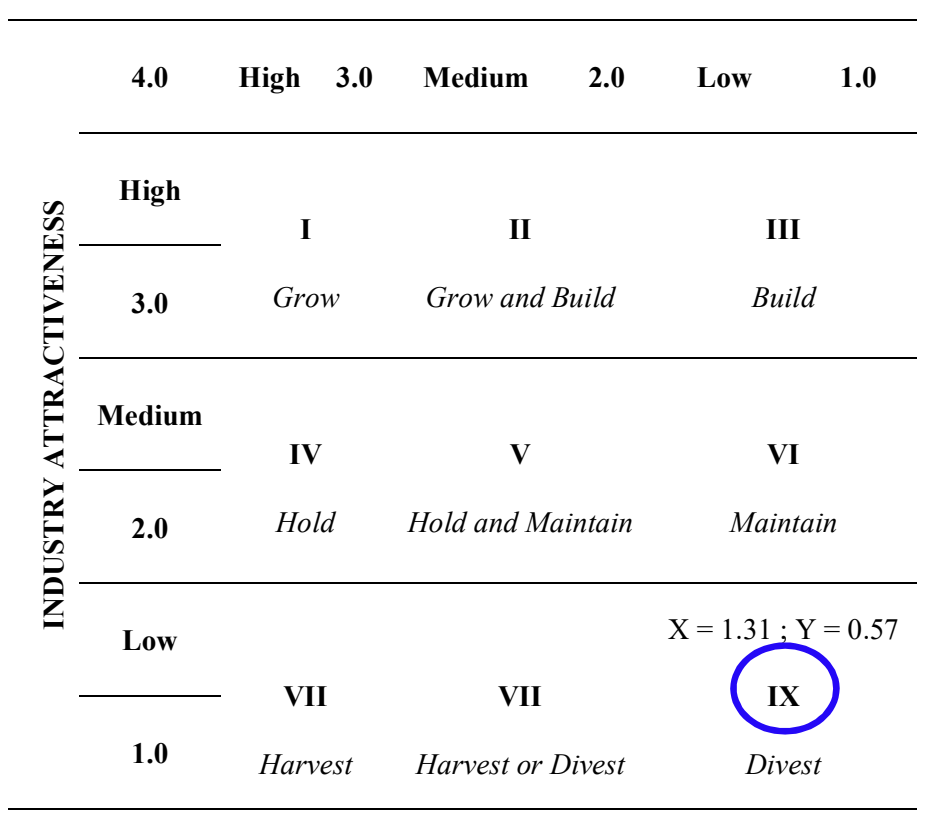

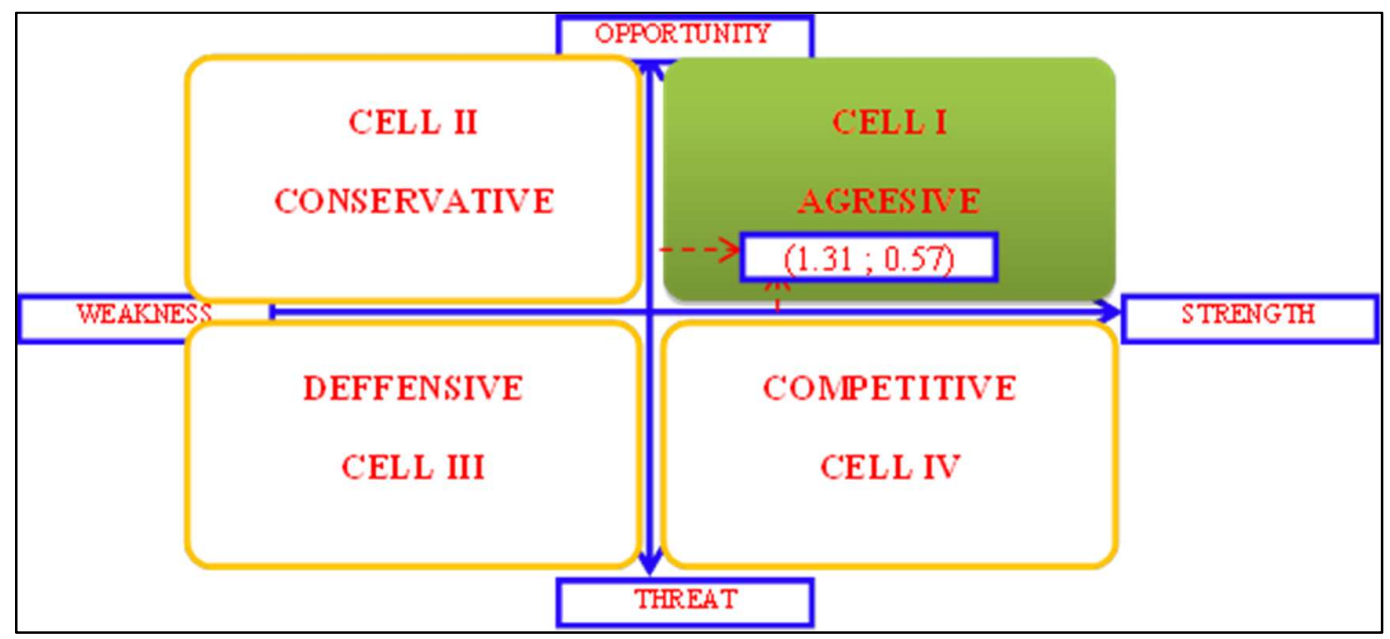

Table 5. Porter's 5 Competitive Industry Forces for Crude Palm Oil Commodity 


\section{New Entrance}

There is a barrier to entry because: requires large-scale investment, labor-intensive, require plenty of labor availability, and require a very extensive plantation in tropical regions.

There are not many new entrances in the industry.

\section{Suppliers}

Has the bargaining power of the Palm Oil commodity prices in the form of raw and processed, which Is a commodity that is traded competitively in world commodity markets, and involves a lot of sellers / buyers.

Indonesia has a good ability as a supplier of CPO but the strength of commodity pricing is determined by the developed countries.
Industry Competitors / Intensive Rivalry

With the increasing number of companies engaged in oil palm plantations and the increasing growth in $\mathrm{CPO}$ production in Indonesia, which is above the level of domestic consumption of Palm Oil, the rivalry between the companies engaged in oil palm plantations is quite high.

With the increasing consumption of Palm Oil in the world, the CPO production in Indonesia will be absorbed in the market. Intensify competition on market seizing occurred at the downstream level, i.e. on advanced derivative products such as cooking oil, margarine, and others.

\section{Substitute}

- Palm Oil is the raw material for both edible and non-edible oil that competes with soybean oil, rapeseed oil, and sunflower oil.

- On the other hand, Palm Oil has the advantage because its Petron processing cost is lower than other raw materials, supplies stable and more resistant to climatic factors (oil from other commodities very prone to the weather), Palm Oil can be harvested in the long term (around 3-25 years after planting).
Have the power to bargain with both Palm Oil prices in raw or processed form, is a commodity that is traded competitively in world commodity markets, and involves a lot of buyers.

Buyer become important determiner in determining the price of Palm Oil commodity in worldwide market 


\subsection{Analysis for Trading on Agricultural Commodities from Indonesia to Turkey}

Palm Oil production has experienced a rapid increase in recent years, contrary to the country's economic developments in Indonesia in 2007 and received his title of being Malaysia's largest manufacturer. Approximately 2 million people are employed in this sector. Nowadays, Indonesia is the second largest rubber producer in the world; Thailand and Malaysia are among the ranks [7]. It carries 85 percent of world production of the three countries. Palm Oil as Palm Oil producing plants and palm kernel is one of the excellent crops who are a source non-oil income for Indonesia. Bright prospects for Palm Oil commodities in world trade of vegetable oils have been motivate Indonesian government to encourage development oil palm plantation area [8] [9]. Palm Oil processing and refining is carried out mainly by large integrated companies. These companies own sizeable plantation areas and Palm Oil mills, and in some cases are further integrated into refineries, oleo chemical factories and biodiesel plants. The characteristics of Palm Oil make it attractive to the food industry. It is easily the cheapest oil on the market (costing about $\$ 1,000$ per metric tons at the end of 2010), although prices are rising sharply [10]. Palm Oil is an important source of edible oil, and also a potential biofuel raw material.

Based on Strength-Weakness-Opportunity-Threat (SWOT) analysis for learning international trading relationship from Indonesia to Turkey was obtained important information, those are:

1. The strengths of the bilateral trading relationship of Indonesia to Turkey, these are: satisfying customer service, sufficient production and transportation facilities, high work discipline level in supply companies, experienced in export business of agricultural commodities, good product quality, the management company running smoothly, and the tropical climate and vast agricultural land.

2. The weaknesses of bilateral trading relationship of Indonesia to Turkey, these are: not all Indonesian agricultural products have certificates of Life Cycle Assessment (LCA) which required by EU, high operating costs, promotional activities are not optimal, the lack of international distribution network, market share is still narrow, less strong capital, and still selling raw materials.

3. The opportunities of bilateral trading relationship of Indonesia to Turkey, these are: national agricultural industry continues to grow, the number of entrepreneurs in agricultural commodities are relatively big, business climate venture in agricultural commodities is relatively good for newcomers, technological advancements in the field of information, communication and transportation, loyal customers from abroad, there is a MoU trade between Indonesia-Turkey, and the amount of Indonesian society that graduate from agricultural science from universities in Turkey is increasing.

4. The threats of bilateral trading relationship of Indonesia to Turkey, these are: business competition is getting tougher, changes in consumer tastes, Indonesia's economic growth is 
running slowly, complicated and burdensome export licensing bureaucracy, high rates of inflation and the weakening of the rupiah, the issue of environmental damage due to poor farming practices, and complicated international trade licensing quarantine.

To get more strong power for improving and expanding trading activity from Indonesia to Turkey needed strategy formulation which increasing the internal strengths and decreasing the weaknesses combined to catch the opportunities and to avoid the threats. The StrengthOpportunity (SO) strategy focused on introducing new and innovative agricultural products to increase the added value, Improve product quality, human resources, and service to maintain the loyal customers in Turkey. The Weakness-Opportunity (WO) strategy pushed on adding investments, technological efficiency, and production capacity and product quality, and adding international distribution network through similar commodity trade associations abroad. The Strength-Threat (ST) concentrated on improving competitiveness through efficiency and quality; also improve the credibility of enterprises through the fulfillment of consumer demand and suitable to international rules. The Weakness-Threat (WT) prioritized on optimizes production capacity and make cost savings and doing strategies concentration on one product line

Based on Internal Factor Analysis (IFAS), the highest score in strength obtained by the first factor that is satisfactory customer service, it gained $+0,44$ point and the lowest score in weakness obtained by seventh factor that is still selling raw materials, it gained $-0,27$ point. The IFAS result is positive, it means that the strength is bigger than the weaknesses and the industry can be face the weakness with their internal strength.

Based on External Factor Analysis (EFAS), the highest score in opportunity obtained by the first factor that is national agricultural industry continues to grow, it gained $+0,48$ point and the lowest score in threat obtained by seventh factor that is complicated international trade licensing quarantine, it gained $-0,27$ point. The EFAS result is positive, it means that the opportunity is bigger than the threats and the industry can be face the threats with opportunities which support of Turkey. Based on the analysis of the internal - external factor matrix, it is known that the condition of trade in agricultural commodities from Turkey to Indonesia was on the ninth of cells, namely the Divest condition $(\mathrm{X}=1.31$; $\mathrm{Y}=0.57)$, where $\mathrm{X}$ is the total value of EFAS and Y is total value of IFAS. In the grand strategy matrix, the position of Indonesia is in a position to aggressively enter Turkey.

Based on Porter's 5 Competitive Forces Matrix for informed that, there is a barrier to entry because: requires large-scale investment, labor-intensive, require plenty of labor availability, and require a very extensive plantation in tropical regions [11]. There are not many new entrances in the industry.Companies has the bargaining power of the Palm Oil commodity prices in the form of raw and processed, which is a commodity that is traded competitively in 
world commodity markets, and involves a lot of sellers / buyers [12]. Indonesia has a good ability as a supplier of CPO but the strength of commodity pricing is determined by the developed countries. With the increasing number of companies engaged in oil palm plantations and the increasing growth in CPO production in Indonesia, which is above the level of domestic consumption of Palm Oil, the rivalry between the companies engaged in oil palm plantations is quite high [13] [24]. With the increasing consumption of Palm Oil in the world, the CPO production in Indonesia will be absorbed in the market. Intensive competition on market seizing occurred at the downstream level on advanced derivative products such as cooking oil, margarine, and others.

Palm Oil is the raw material for both edible and non-edible oil that competes with soybean oil, rapeseed oil, and sunflower oil. On the other hand, Palm Oil has the advantage because its Perton processing cost is lower than other raw materials, supplies stable and more resistant to climatic factors (oil from other commodities very prone to the weather), Palm Oil can be harvested in the long term (around 3-25 years after planting) [10].

\section{Conclusion and Recommendation/Policy Implication}

Diplomatic relationship between Indonesia and Turkey day by day have been increasing in Agriculture, Economy, Military, Cultre, and Education. This condition is very good as starting point to deepens relation between Indonesia and Turkey. But unfortunately, curently in Economic Sector especially Agriculture, the collaboration the responsible organisations is still low. Thus, between two countries should be doing more cooperation related in Agriculture Sector.

\section{REFERENCES}

[1] Ministry of the Republic of Indonesia Secretariat of State Government Office, 2012. [Online]. Availabel: $\underline{\text { http://www.setkab.go.id }}$

[2] Official news statistics (Berita Resmi Statistik), 2013. [Online]. Available: http://www.bps.go.id

[3] L. W. Briggle and B. C. Curtis, "Wheat worldwide: wheat and wheat improvement in E.G.Heyne (Editor)," Agronomy, vol. 13, 1987.

[4] H. O Eruygur and E. H. Cakmak, "Turkey's imports of agricultural products and EU: an empirical assessment of membership, paper presented at the conference of the channels of european integration (to be published at conference proceedings)," Warsaw: Poland, October 7-8, 2005.

[5] T. R. Nurul, Gumbira. E., Sa'id., D. Arief, and N. Nunung, "Analysis of Indonesian agroindustry competitiveness in nanotechnology development perspective using SWOT-AHP method," International Journal of Business and Management, vol. 6, no. 8, 2011. [Online]. Available: http://www.ccsenet.org

[6] F. Rangkuti, Analisis SWOT: teknik membedah kasus bisnis (technique dissecting the business case). Jakarta: PT. Gramedia Pustaka Utama, 2005.

[7] M. N. Amiruddin, "Palm Oil products exports, prices and export duties: Malaysia and Indonesia compared," Oil Palm Industry Economic Journal, vol. 3, no. 2, 2003. [Online]. Available: http://www.chgs.com.my/ 
[8] Indonesia Investment Coordinating Board Official Website, "Indonesian Palm Oil Statistics 2008, Agriculture Ministry,” Jakarta. [Online]. Available: http://www.bkpm.go.id

[9] World Bank, "World development report 2008: agriculture for development," Washington, DC: World Bank. [Online]. Available: http://siteresources.worldbank.org

[10] Directorate General of Plantation, "Statistics Plantation Indonesia, 2008: Palm Oil,”, Jakarta.

[11] Indonesia investment Coordinating Board, 2011, Macro Development in Agribusiness Sector. Retrived from: http://www.bkpm.go.id [Accessed 26 February 2014].

[12] Carter, C., Finley, W., Fry, J., Jackson, D. and Willis, L, 2007, Palm Oil markets and future supply. European Journal of Lipid Science and Technology Vol. 109: 307-314.

[13] Data Center and Information of the Secretariat General for the Ministry of Industry (Pusat Data dan Informasi Sekretariat Jendral Kementerian Perindustrian) Republic of Indonesia, 2007, Gambaran sekilas industri kelapa sawit. Retrived from: http://www.kemenperin.go.id [Accessed 20 September 2013].

[14] Sargeant, H. J., 2001, Oil palm agriculture in the wetlands of Sumatra: destruction or development? European Union Ministry of Forestry, Brussels. 